Jurnal Ilmu-Ilmu Peternakan 25 (1): 24 - 34

ISSN: 0852-3581

E-ISSN: 9772443D76DD3

CFakultas Peternakan UB, http://jiip.ub.ac.id/

\title{
Distribusi komponen karkas sapi Brahman Cross (BX) hasil penggemukan pada umur pemotongan yang berbeda
}

\author{
Muhamad Iqbal Zajulie, Moch Nasich,Trinil Susilawati dan Kuswati \\ Fakultas Peternakan Universitas Brawijaya Malang \\ Jl. Veteran Malang 65145 Jawa Timur \\ trinil_susilawati@yahoo.com
}

\begin{abstract}
The aim of this study was to determine the distribution of beef carcass component from Brahman Cross cattle at different slaughtered age. The number of cattle was 99 head (49 steers and 50 heifers), the body weight 350 - $500 \mathrm{~kg}$ and age ranged $\mathrm{PI}_{0}-\mathrm{PI}_{2}$ classess. The cattle were raised in PT. Widodo Makmur Perkasa and then slaughtered at slaughter house in Cianjur District, West Java. Accidental sampling method was applied to the research. A direct observation was done to obtain information about age, sex, body weight and carcass weight and its part (meat, bone and fat). The data were analyzed using independent $t$-test, correlation and linear regresion. The result showed that the average slaughtered weight and carcas weight of Brahman Cross heifers was higher than that of Brahman Cross steers at $\mathrm{PI}_{0}$ sex-class $(\mathrm{P}<0.05)$. However, the dressing percentage was relatively similar $(\mathrm{P}>0.05)$. Average meat percentage of heifers and steers was also relatively similar $(73.39 \%: 73.65 \%)$. Average bone percentage of steers was higher than that of heifers $(14.82 \%: 14.33 \%)$. Whereas, average fat percentage of heifers was higher than that of steers $(11.00 \%: 10.21 \%)$. The research concluded that steers of Brahman Cross cattle at all age-classess had better distribution of carcass component than heifers in the same age-classess. Steers of Brahman Cross cattle at $\mathrm{PI}_{2}$ slaughtered age-class had an optimal distribution of carcass components.
\end{abstract}

Keyword: Brahman Cross, slaughtered age, sex-class, distribution, carcas component.

\section{PENDAHULUAN}

Permintaan daging dari tahun ke tahun terus mengalami peningkatan seiring engan pertambahan jumlah penduduk, pertumbuhan ekonomi dan juga kesadaran masyarakat terhadap pentingnya kebutuhan protein hewan. Kebutuhan daging sapi di Indonesia sampai saat ini dipenuhi dari tiga sumber yaitu ternak sapi lokal, sapi impor, dan impor daging beku dari luar negeri dimana $14 \%$ dari total kebutuhan daging dalam negeri masih berasal dari luar negeri yang diimpor dalam bentuk daging beku maupun sapi bakalan. Sapi potong yang dijadikan bakalan pada industri penggemukan di Indonesia diimpor dari Australia. Jenis bangsa dari bakalan tersebut adalah sapi Brahman Cross (BX).

Produk utama yang dihasilkan setelah ternak disembelih adalah karkas. Seekor sapi potong dianggap baik apabila dapat menghasilkan karkas sebesar 59\% dari bobot badan sapi dan diperoleh $46,50 \%$ daging yang dapat 
dikonsumsi. Average Daily Gain (ADG) sapi BX berkisar antara 1,0-1,8 $\mathrm{kg} / \mathrm{hari}$, bahkan dalam kondisi tertentu bisa mencapai $2 \mathrm{~kg} / \mathrm{hari}$. Karkas Brahman Cross bervariasi antara $45 \%$ $55 \%$ tergantung kondisi sapi saat ditimbang hidup dan performan tiap individunya (Mustofa, 2001).

Produksi karkas seekor ternak dipengaruhi oleh beberapa faktor antara lain jenis kelamin, umur dan nutrisi (Berg and Butterfield, 1976 dalam Usmiati, dkk, 2008). Soeparno (2005) menyatakan bahwa bobot potong yang tinggi menghasilkan karkas yang makin besar sehingga diharapkan bagian daging menjadi lebih besar. Jenis kelamin (sex) mempengaruhi pertumbuhan jaringan dan komposisi karkas.

PT. Widodo Makmur Perkasa merupakan salah satu perusahaan penggemukan sapi potong terbesar di Indonesia dengan kapasitas pemeliharaan sebanyak 21.000 ekor yang terletak di Desa Mentengsari, Kecamatan Cikalong Kulon, Kabupaten Cianjur. Bangsa sapi yang dipelihara adalah sapi bakalan impor yaitu sapi BX. Manajemen penggemukan yang digunakan adalah sistem feedlot fatttening yang bertujuan menghasilkan pertambahan bobot badan yang tinggi dengan penggunaan pakan yang efisien sehingga menghasilkan karkas yang mempunyai kualitas maupun kuantitas optimal. Berdasarkan uraian tersebut penelitian ini bertujuan untuk mengetahui distribusi komponen karkas sapi BX pada berbagai umur pemotongan antara heifer dan steer hasil penggemukan di PT. Widodo Makmur Perkasa.

\section{MATERI DAN METODE}

Materi yang digunakan dalam penelitian ini adalah sapi Brahman Cross (BX) hasil penggemukan di PT.
Widodo Makmur Perkasa Cianjur, Jawa Barat yang dipotong (disembelih) di beberapa RPH di Kabupaten Cianjur. Jumlah sapi yang diteliti sebanyak 99 ekor yang terdiri dari 49 ekor steer dan 50 ekor heifer dengan rata-rata bobot potong $350-500 \mathrm{~kg}$ dan kisaran umur $\mathrm{PI}_{0}-\mathrm{PI}_{2}$. Peralatan yang digunakan adalah timbangan digital merek "Matrix" untuk penimbangan bobot potong kapasitas $2000 \mathrm{~kg}$ dengan ketelitian $1 \mathrm{~kg}$, timbangan karkas merek "Quattro" kapasitas 1000 kg dengan ketelitian $0,5 \mathrm{~kg}$, timbangan daging kapasitas $500 \mathrm{~kg}$ dengan skala ketelitian 0,1 kg merek "Quattro" dan seluruh fasilitas peralatan Rumah Potong Hewan (RPH) di Kabupaten Cianjur.

\section{Analisis data}

Analisis data dengan uji "t-tidak berpasangan" dilakukan untuk mengetahui pengaruh perbedaan umur pemotongan dan jenis kelamin terhadap produktivitas dan distribusi komponen karkas. Rumus yang digunakan menurut Sastrosupadi (2000) adalah:

$$
\begin{aligned}
& t_{\text {hitung }}=\frac{\left|\boldsymbol{X}_{A}-X_{B}\right|}{\sqrt{\left[S^{2}\left(\frac{1}{n_{A}}+\frac{1}{n_{B}}\right)\right]}} \\
& S^{2}=\frac{\left(n_{A}-1\right)\left(S_{A}^{2}\right)+\left(n_{B}-1\right)\left(S_{B}^{2}\right)}{\left(n_{A}-1\right)+\left(n_{B}-1\right)}
\end{aligned}
$$

Keterangan:

$\boldsymbol{X}_{A}=$ Rata-rata kelompok A

$\boldsymbol{n}_{\boldsymbol{A}}=$ Jumlah sampel pada kelompok A

$\boldsymbol{X}_{\boldsymbol{B}}=$ Rata-rata kelompok B

$\boldsymbol{n}_{\boldsymbol{B}}=$ Jumlah sampel pada kelompok B

$S_{A}^{2}=$ Standar deviasi kelompok A

$\boldsymbol{S}_{B}^{2}=$ Standar deviasi kelompok B

$S^{2}=$ Standar deviasi gabungan

Nilai koefisien korelasi dapat dihitung secara manual dengan menggunakan rumus sebagai berikut : 


$$
r=\frac{\sum X Y-\frac{\left(\sum X \sum Y\right)}{n}}{\sqrt{\sum X^{2}-\frac{\left(\sum X\right)^{2}}{n}} \sqrt{\sum X^{2}-\frac{\left(\sum Y\right)^{2}}{n}}}
$$

\section{HASIL DAN PEMBAHASAN}

Hasil rataan bobot potong, bobot karkas dan persentase karkas sapi BX antara heifer dan steer ditampilkan pada Tabel 1.

Tabel 1. Rataan bobot potong, bobot karkas dan persentase karkas sapi BX heifer dan steer pada berbagai umur pemotongan

\begin{tabular}{ccccc}
\hline No & Indikator produktifitas & Umur & \multicolumn{2}{c}{ Rata-rata \pm sd } \\
\cline { 3 - 5 } & & Heifer & Steer \\
\hline \multirow{3}{*}{1} & \multirow{3}{*}{ Bobot potong $(\mathrm{kg})$} & $\mathrm{PI}_{0}$ & $418,53 \pm 33,57^{\mathrm{c}}$ & $352,75 \pm 40,81^{\mathrm{d}}$ \\
& $\mathrm{PI}_{1}$ & $449,58 \pm 44,00$ & $442,50 \pm 41,95$ \\
& $\mathrm{PI}_{2}$ & $476,00 \pm 46,67$ & $505,06 \pm 42,95$ \\
\cline { 3 - 5 } & $\mathrm{Rataan}$ & $446,08 \pm 45,98$ & $455,63 \pm 41,90$ \\
\hline \multirow{3}{*}{2} & \multirow{3}{*}{ Bobot karkas (kg) } & $\mathrm{PI}_{0}$ & $228,46 \pm 24,43^{\mathrm{a}}$ & $192,50 \pm 31,64^{\mathrm{b}}$ \\
& & $\mathrm{PI}_{1}$ & $247,20 \pm 28,70$ & $242,93 \pm 25,48$ \\
& $\mathrm{PI}_{2}$ & $258,00 \pm 21,00^{\mathrm{a}}$ & $280,00 \pm 28,76^{\mathrm{b}}$ \\
\cline { 3 - 5 } 3 & $\mathrm{Rataan}$ & $243,96 \pm 27,75$ & $250,91 \pm 36,12$ \\
\hline \multirow{3}{*}{ Persentase karkas (\%) } & $\mathrm{PI}_{0}$ & $54,51 \pm 2,24$ & $54,37 \pm 3,17$ \\
& $\mathrm{PI}_{1}$ & $54,91 \pm 2,42$ & $54,89 \pm 2,51$ \\
& & $\mathrm{PI}_{2}$ & $54,29 \pm 1,83$ & $55,40 \pm 2,44$ \\
\cline { 3 - 4 } & & $\mathrm{Rataan}$ & $54,65 \pm 2,22$ & $55,01 \pm 2,50$ \\
\hline
\end{tabular}

Keterangan : superskrip (a-b) pada baris yang sama menunjukkan perbedaan yang nyata $(\mathrm{P}<0,05)$

superskrip (c-d) pada baris yang sama menunjukkan perbedaan yang sangat nyata $(\mathrm{P}<0,01)$

Tabel 1 menunjukkan bahwa ratarata bobot potong sapi $\mathrm{BX}$ heifer dan steer cenderung meningkat seiring dengan bertambahnya umur ternak. Hasil analisis menunjukkan bahwa heifer pada kelompok umur $\mathrm{PI}_{0}$ mempunyai bobot potong lebih tinggi $(\mathrm{P}<0,01)$ dibandingkan dengan steer pada umur yang sama. Hal ini terjadi karena heifer mempunyai tingkat kematangan yang lebih cepat daripada steer, sehingga pada umur yang lebih muda pertumbuhan pada heifer lebih cepat daripada steer. Bertram and Oliver (1990) dalam Usmiati, dkk (2008) menyatakan bahwa heifer mencapai tingkat kedewasaan yang lebih awal dan mempunyai masa penggemukan yang lebih cepat dari pada steer, namun heifer mempunyai pertambahan bobot badan yang lebih rendah dan kurang efisien dalam mengkonversi pakan. Pada kelompok umur $\mathrm{PI}_{1}$ dan $\mathrm{PI}_{2}$, bobot potong heifer dan steer tidak menunjukkan perbedaan yang nyata $(\mathrm{P}>0,05)$. Namun demikian, dilihat dari nilai rata-rata, heifer mempunyai bobot potong yang lebih tinggi pada kelompok umur $\mathrm{PI}_{0}$ dan $\mathrm{PI}_{1}$. Hal ini mungkin terjadi karena steer merupakan sapi jantan yang telah dikastrasi sehingga sapi tersebut 
kehilangan hormon testosteron yang menyebabkan pertumbuhannya terhambat. Hal ini sesuai dengan pendapat Hafid (2002) yang menyatakan bahwa testosteron atau androgen merupakan suatu hormon steroid yang dihasilkan oleh testis yang menyebabkan pertumbuhan ternak jantan lebih cepat dibandingkan betina terutama setelah timbulnya pubertas. Soeparno (2005) menyatakan bahwa kastrasi mengubah sistem hormonal ternak jantan sehingga mengakibatkan perubahan komposisi tubuh dan karkas.

Heifer pada kelompok umur $\mathrm{PI}_{2}$ mempunyai bobot potong yang lebih rendah daripada steer, namun secara statistik tidak menunjukkan perbedaan yang nyata. Hafid dan Priyanto (2006) menyatakan bahwa sapi dara (heifer) menyelesaikan fase penggemukan yang lebih cepat dibandingkan dengan sapi jantan kastrasi (steer). Oleh karena itu bobot potong optimal sapi dara lebih kecil daripada sapi jantan kastrasi.

Karkas sebagai satuan produksi dinyatakan dalam bobot karkas dan persentase karkas. Bobot karkas mempunyai hubungan yang erat dengan bobot potong (Soeparno, 2005). Hal tersebut sesuai dengan hasil analisis yang menunjukkan bahwa heifer pada kelompok umur $\mathrm{PI}_{0}$ mempunyai bobot karkas yang secara nyata lebih tinggi $(\mathrm{P}<0,05)$ daripada steer pada umur yang sama. Hal ini terjadi karena sapi BX heifer pada kelompok umur tersebut mempunyai bobot potong yang lebih tinggi dibandingkan dengan steer pada kelompok umur yang sama. Pada kelompok umur $\mathrm{PI}_{1}$, bobot karkas antara heifer dan steer tidak menunjukkan perbedaan yang nyata $(\mathrm{P}>0,05)$. Hal ini terjadi karena kedua kelompok umur tersebut mempunyai bobot potong yang hampir sama, sehingga menghasilkan bobot karkas yang hampir sama pula. Sedangkan pada kelompok umur $\mathrm{PI}_{2}$, steer mempunyai bobot karkas yang secara nyata lebih tinggi $(\mathrm{P}<0,05)$ dibandingkan dengan heifer. Hal ini terjadi karena steer pada kelompok umur tersebut mempunyai bobot potong yang lebih tinggi dibandingkan heifer. Bobot karkas yang lebih tinggi pada kelompok umur $\mathrm{PI}_{2}$ dibandingkan dengan bobot karkas pada kelompok umur $\mathrm{PI}_{1}$ dan $\mathrm{PI}_{0}$ dikarenakan perbedaan umur.

Hasil analisis menunjukan bahwa persentase karkas heifer dan steer pada kelompok umur $\mathrm{PI}_{0}$ dan $\mathrm{PI}_{1}$ tidak memiliki perbedaan yang nyata $(\mathrm{P}>0,05)$ walaupun bobot potong heifer pada kelompok umur tersebut lebih tinggi dibandingkan bobot potong steer. Begitu pula pada kelompok umur $\mathrm{PI}_{2}$ dimana steer mempunyai persentase karkas yang hampir sama dengan heifer $(\mathrm{P}>0,05)$, walaupun bobot potong steer lebih tinggi dibandingkan dengan bobot potong heifer. Hal ini mungkin terjadi karena pada kelompok umur ternak yang mempunyai bobot potong tinggi mempunyai bobot non karkas yang tinggi pula sehingga mengurangi persentase karkas. Hal tersebut sesuai dengan pendapat Purbowati, dkk (2011) yang menyatakan bahwa persentase karkas dipengaruhi oleh bobot potong dan bobot komponen tubuh yang terdiri dari komponen karkas dan komponen non karkas.

Persentase karkas paling rendah terdapat pada sampel sapi BX heifer pada kelompok umur $\mathrm{PI}_{2}$ $(54,29 \pm 1,83 \%)$, sedangkan persentase karkas tertinggi terdapat pada sampel sapi BX steer $\mathrm{PI}_{2}(55,40 \pm 2,44 \%)$.

Pengaruh pemberian pakan dan minum sebelum pemotongan pada saat penelitian menyebabkan adanya variasi bobot isi saluran pencernaan yang secara tidak langsung mempengaruhi persentase karkas. Hal ini sesuai dengan penelitian Hafid dan Priyanto (2006) 
yang menyatakan bahwa sapi yang tidak dipuasakan tidak mengalami penyusutan bobot hidup sehingga persentase karkas yang dihasilkan lebih rendah. Hafid (2002) menyatakan bahwa faktor yang turut mempengaruhi persentase karkas adalah volume pakan dan air minum yang mengisi saluran pencernaan,artinya semakin sedikit pakan dan air minum dalam alat pencernaan dan kantung kemi maka persentase karkas semakin tinggi.

Kualitas karkas sangat ditentukan oleh imbangan ketiga komponen karkas tersebut. Distribusi komponen karkas sapi BX heifer dan steer hasil penelitian ditampilkan pada Tabel 2.

Tabel 2. Tampilan distribusi komponen karkas sapi BX heifer dan steer pada berbagai umur pemotongan

\begin{tabular}{|c|c|c|c|c|c|c|}
\hline \multirow{2}{*}{ No } & \multirow{2}{*}{$\begin{array}{l}\text { Komponen } \\
\text { karkas }\end{array}$} & \multirow{2}{*}{ Umur } & \multicolumn{2}{|c|}{ Rata rata $\pm \mathrm{sd}(\mathrm{kg})$} & \multicolumn{2}{|c|}{$\begin{array}{c}\text { Persentase rata-rata } \pm \mathrm{sd} \\
(\%)\end{array}$} \\
\hline & & & Heifer & Steer & Heifer & Steer \\
\hline \multirow{4}{*}{1} & \multirow{4}{*}{ Daging } & $\mathrm{PI}_{0}$ & $166,19 \pm 20,80^{a}$ & $139,87 \pm 27,47^{\mathrm{b}}$ & $72,68 \pm 3,35$ & $72,38 \pm 2,29$ \\
\hline & & $\mathrm{PI}_{1}$ & $182,11 \pm 23,21$ & $179,38 \pm 20,84$ & $73,58 \pm 1,91$ & $73,77 \pm 1,84$ \\
\hline & & $\mathrm{PI}_{2}$ & $190,49 \pm 12,80$ & $206,50 \pm 22,01$ & $73,92 \pm 2,24$ & $73,75 \pm 1,89$ \\
\hline & & Rataan & $179,18 \pm 22,26$ & $185,01 \pm 28,19$ & $73,39 \pm 2,49$ & $73,65 \pm 1,89$ \\
\hline \multirow{4}{*}{2} & \multirow{4}{*}{ Tulang } & $\mathrm{PI}_{0}$ & $33,80 \pm 4,40$ & $32,40 \pm 1,31$ & $14,87 \pm 2,04$ & $17,10 \pm 2,26$ \\
\hline & & $\mathrm{PI}_{1}$ & $34,58 \pm 3,53$ & $36,62 \pm 4,49$ & $14,06 \pm 1,20$ & $15,16 \pm 1,91$ \\
\hline & & $\mathrm{PI}_{2}$ & $36,88 \pm 4,39$ & $38,06 \pm 3,49$ & $14,27 \pm 0,86$ & $13,64 \pm 1,08$ \\
\hline & & Rataan & $34,85 \pm 4,10^{\mathrm{a}}$ & $36,74 \pm 4,22^{b}$ & $14,33 \pm 1,46$ & $14,82 \pm 1,94$ \\
\hline \multirow{4}{*}{3} & \multirow{4}{*}{ Lemak } & $\mathrm{PI}_{0}$ & $25,29 \pm 4,50^{\mathrm{c}}$ & $17,52 \pm 2,36^{\mathrm{d}}$ & $11,06 \pm 1,50^{\mathrm{a}}$ & $9,13 \pm 0,34^{b}$ \\
\hline & & $\mathrm{PI}_{1}$ & $27,65 \pm 5,11^{\mathrm{c}}$ & $23,85 \pm 4,79^{d}$ & $11,19 \pm 1,71^{\mathrm{c}}$ & $9,79 \pm 1,45^{\mathrm{d}}$ \\
\hline & & $\mathrm{PI}_{2}$ & $28,17 \pm 6,46$ & $31,58 \pm 6,23$ & $10,84 \pm 1,77$ & $11,24 \pm 1,76$ \\
\hline & & Rataan & $27,05 \pm 5,29$ & $25,86 \pm 6,71$ & $11,00 \pm 1,63^{\mathrm{a}}$ & $10,21 \pm 1,66^{\mathrm{b}}$ \\
\hline
\end{tabular}

Keterangan : superskrip (a-b) pada baris yang sama menunjukkan perbedaan yang nyata $(\mathrm{P}<0,05)$

superskrip (c-d) pada baris yang sama menunjukkan perbedaan yang sangat nyata $(\mathrm{P}<0,01)$

Tabel 2 menunjukkan bahwa komponen karkas sapi BX heifer dan steer mengalami peningkatan seiring dengan bertambahnya umur. Daging merupakan komponen karkas yang terpenting sehingga dalam penerapannya, total daging secara kumulatif dipergunakan sebagai titik akhir sarana penduga atau pengukur komposisi karkas (Berg and Butterfield 1976). Rataan bobot daging heifer pada kelompok $\mathrm{PI}_{0}$ mempunyai nilai yang lebih tinggi $(\mathrm{P}<0,05)$ dibandingkan dengan bobot daging steer pada umur yang sama. Bobot daging pada kelompok umur $\mathrm{PI}_{1}$ menunjukkan bahwa heifer mempunyai nilai yang lebih tinggi dibandingkan steer, namun secara analisis tidak menunjukkan perbedaan yang nyata $(\mathrm{P}>0,05)$. Pada kelompok umur $\mathrm{PI}_{2}$, steer mempunyai bobot daging yang lebih tinggi dibandingkan dengan heifer, namun secara analisis tidak menunjukkan perbedaan yang nyata. Bobot daging steer yang lebih kecil pada kelompok 
umur $\mathrm{PI}_{0}$ dan $\mathrm{PI}_{1}$ dibandingkan bobot daging heifer pada umur yang sama kemungkinan besar terjadi karena heifer mempunyai tingkat kematangan yang lebih cepat daripada steer, sehingga pada umur yang lebih muda pertumbuhan tulang pada heifer berhenti lebih awal dan kemudian digantikan dengan pertumbuhan daging yang lebih cepat daripada steer. Bertram and Oliver (1990) menyatakan bahwa heifer mencapai tingkat kedewasaan yang lebih awal dan mempunyai masa penggemukan yang lebih cepat daripada steer, namun heifer mempunyai pertambahan bobot badan yang lebih rendah dan kurang efisien dalam mengkonversi pakan. Usmiati, dkk (2008) menyatakan bahwa pada bobot tubuh dan bobot karkas yang sama, ternak jantan mempunyai lebih banyak daging dan tulang serta sedikit lemak dibandingkan ternak betina. Perbedaan bobot daging dari ketiga kelompok umur pemotongan antara heifer dan steer sapi BX dikarenakan perbedaan umur dari masing-masing individu ternak, dimana bobot potong ternak pada umur muda lebih kecil dibandingkan bobot potong ternak pada umur dewasa. Usmiati, dkk (2008) menyatakan bahwa hasil bobot daging yang lebih rendah pada ternak muda disebabkan karena ukuran tubuh ternak muda belum maksimal dan masih mengalami pertumbuhan yaitu terjadi pembelahan sel-sel sampai bobot tubuh tertentu yang selanjutnya mengalami diferensiasi pada umur tertentu (dewasa kelamin) yang dikenal dengan perkembangan.

Rata-rata bobot daging tertinggi $(206,5 \pm 22,01 \mathrm{~kg})$ terdapat pada sampel sapi BX steer pada kelompok umur pemotongan $\mathrm{PI}_{2}$, sedangkan rata-rata bobot daging terendah $(139,87 \pm 27,47$ $\mathrm{kg}$ ) terdapat pada steer kelompok umur $\mathrm{PI}_{0}$. Berdasarkan hasil analisis persentase daging antara heifer dan steer pada ketiga kelompok umur tidak menunjukkan perbedaan yang nyata $(\mathrm{P}>0,05) \quad$ pada masing-masing kelompok umur. Namun demikian, nilai persentase daging tertinggi $(73,92 \pm 2,24 \%)$ terdapat pada heifer kelompok umur $\mathrm{PI}_{2}$ sedangkan persentase daging terendah $(72,38 \pm 2,29 \%)$ terdapat pada steer kelompok umur $\mathrm{PI}_{0}$.

Bobot tulang heifer dan steer sapi BX secara umum meningkat seiring dengan pertambahan umur. Hasil analisis menunjukkan tidak ada perbedaan yang nyata antara bobot tulang heifer dan steer pada semua kelompok umur $(\mathrm{P}>0,05)$. Nilai rataan bobot tulang heifer pada kelompok umur $\mathrm{PI}_{0}$ lebih besar dari steer $(33,8 \pm 4,4 \mathrm{~kg}$ dan $32,4 \pm 1,31 \mathrm{~kg})$. Sedangkan pada kelompok umur $\mathrm{PI}_{1}$ dan $\mathrm{PI}_{2}$ rataan bobot tulang steer mempunyai nilai yang lebih tinggi daripada heifer yaitu $(36,62 \pm 4,49 \mathrm{~kg}$ dan $34,58 \pm 3,53 \mathrm{~kg})$ dan $(38,06 \pm 3,49 \mathrm{~kg}$ dan $36,88 \pm 4,39 \mathrm{~kg}$ ). Namun demikian, rataan bobot tulang antara heifer dan steer dari seluruh kelompok umur pemotongan secara analisis menunjukkan perbedaan yang nyata $(\mathrm{P}<0,05)$ dimana steer mempunyai bobot tulang yang lebih tinggi dibandingkan dengan heifer. Hal ini sesuai dengan hasil penelitian Usmiati, dkk (2008) yang menyatakan perbedaan bobot tulang pada ternak jantan lebih berat dibandingkan bobot tulang ternak betina karena bobot hidup ternak jantan lebih berat dibandingkan dengan ternak betina. Persentase tulang tertinggi $(17,10 \pm 2,26 \%) \quad$ terdapat pada steer kelompok umur $\mathrm{PI}_{0}$. sedangkan persentase tulang terendah $(13,64 \pm 1,08 \%)$ terdapat pada steer kelompok umur $\mathrm{PI}_{2}$.

Bobot lemak heifer pada kelompok umur $\mathrm{PI}_{0}$ dan $\mathrm{PI}_{1}$ mempunyai 
nilai rataan yang lebih tinggi $(\mathrm{P}<0,05)$ dibandingkan dengan steer yaitu $(25,29 \pm 4,5 \mathrm{~kg}$ dan $17,52 \pm 2,36 \mathrm{~kg})$ dan $(27,65 \pm 5,11 \mathrm{~kg}$ dan $23,85 \pm 4,79 \mathrm{~kg})$. Sedangkan pada kelompok umur $\mathrm{PI}_{1}$, heifer mempunyai nilai rataan bobot lemak yang lebih rendah daripada steer. Kemungkinan besar hal ini terjadi karena heifer pada kelompok umur $\mathrm{PI}_{1}$ dan $\mathrm{PI}_{2}$ mempunyai bobot komponen daging dan tulang yang lebih rendah daripada steer pada umur yang sama. Hal tersebut sesuai dengan Soeparno (2005) yang menyatakan bila proporsi salah satu komponen karkas lebih tinggi maka proporsi salah satu atau kedua komponen lainnya lebih rendah dan sebaliknya. Nilai rataan bobot lemak steer yang lebih tinggi daripada heifer pada kelompok umur $\mathrm{PI}_{2}$ kemungkinan terjadi karena steer pada kelompok umur $\mathrm{PI}_{2}$ mempunyai bobot karkas yang tinggi. Hal ini sesuai dengan Usmiati, dkk (2008) yang menyatakan bahwa peningkatan bobot karkas biasanya diikuti oleh pertambahan persentase lemak serta penurunan persentase daging dan tulang. Persentase lemak tertinggi $(11,24 \pm 1,76 \%)$ terdapat pada steer kelompok umur $\mathrm{PI}_{2}$, sedangkan persentase lemak terendah $(9,13 \pm 0,34$ $\%)$ terdapat pada steer kelompok umur $\mathrm{PI}_{0}$.

Hasil penelitian menunjukkan bahwa kelompok umur ternak yang lebih tua mempunyai bobot lemak yang lebih tinggi dibandingkan dengan ternak muda. Hal ini sesuai dengan Usmiati, dkk (2008) yang menyatakan bahwa setelah umur ternak dewasa terjadi penimbunan lemak pada beberapa bagian tubuh, di bawah kulit dan di sekitar organ dalam perkembangan deposisi lemak tubuh antara lain lemak intermuskuler, perineal, ginjal, subkutan dan omental.

Perbedaan distribusi komponen daging, tulang dan lemak menunjukkan adanya perbedaan pola pertumbuhan dari masing-masing individu ternak. Perubahan proporsi antara komponen karkas (daging, tulang dan lemak) sejalan dengan pola pertumbuhan pada ternak, dimana tulang berkembang paling awal pada masa pertumbuhan, daging merupakan komponen karkas yang tumbuh setelah tulang, sedangkan lemak adalah jaringan yang tumbuh terakhir (Kuswati, et al, 2014).

Bobot potong dan bobot karkas merupakan suatu indikator produktifitas ternak yang sangat penting dan tidak dapat dipisahkan satu dengan lainnya karena keduanya saling berhubungan. Persamaan korelasi, koefisien korelasi dan koefisien determinasi sapi BX heifer dan steer hasil penelitian disajikan pada Gambar 1 dan 2.

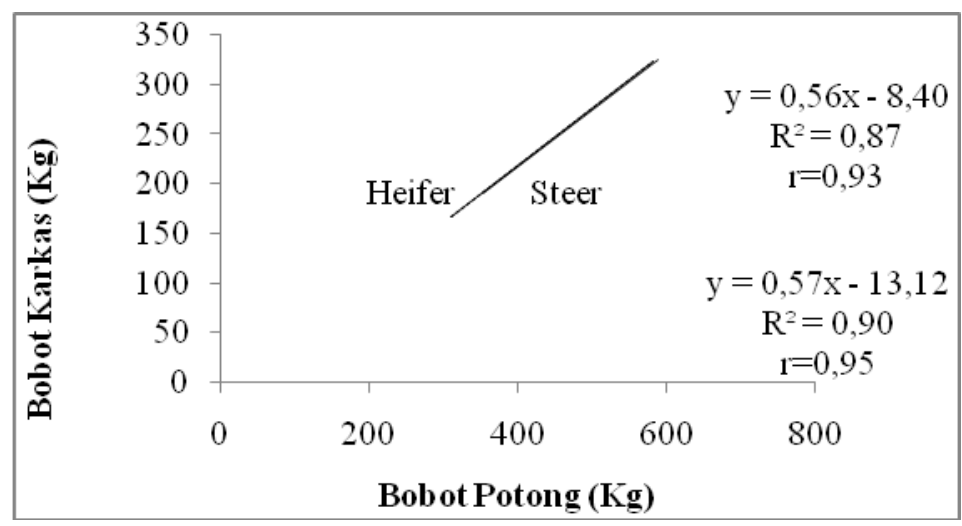

Gambar 1. Hubungan antara bobot potong dengan bobot karkas heifer dan steer 


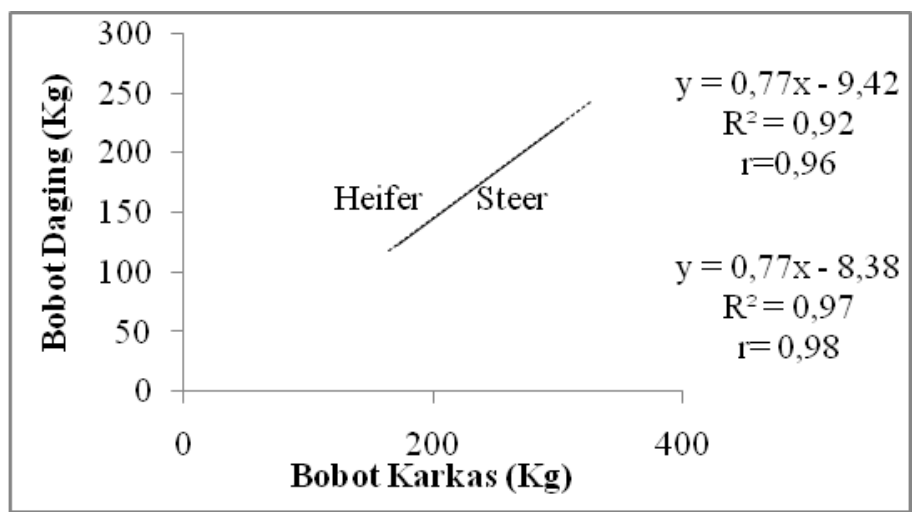

Gambar 2. Hubungan antara bobot karkas dan bobot daging heifer dan steer

Gambar 1 dan 2 menunjukkan korelasi antara bobot potong dengan bobot karkas dan bobot karkas dengan bobot daging sapi BX heifer dan steer. Hasil analisis korelasi menunjukkan bahwa steer mempunyai hubungan keeratan yang lebih tinggi daripada heifer pada hubungan bobot potong dengan bobot karkas dan juga bobot karkas dengan bobot daging. Soeparno (2005) menyatakan bahwa bobot potong dengan bobot karkas berhubungan dengan pertumbuhan dimana pertambahan umur akan menyebabkan pertambahan berat badan dan akan diikuti dengan pertambahan bobot karkas. Sugiyono (2005) menyatakan bahwa nilai koefisien korelasi antara 0,8-1,00 menunjukkan hubungan yang sangat kuat antara bobot karkas dengan bobot daging pada heifer maupun steer. Hubungan antara variabel-variabel tersebut menghasilkan sebuah persamaan regresi yang mempunyai nilai berbeda. Bobot potong dan bobot karkas heifer membentuk sebuah persamaan $\mathrm{Y}=0,56 \mathrm{x}-8,40$. Nilai 8,40 mengindikasikan bila bobot potong pada heifer memiliki nilai nol saja, maka bobot karkasnya sudah mempunyai nilai sebesar $8,40 \mathrm{~kg}$. Sedangkan nilai 0,56 berarti setiap kenaikan $1 \mathrm{~kg}$ bobot potong pada heifer akan meningkatkan $0,56 \mathrm{~kg}$ bobot karkas. Nilai kenaikan tesebut didapat dari hasil kali antara koefisien (b) dengan nilai $(\mathrm{X})$. Koefisien determinasi $\left(R^{2}\right)$ sebesar 0,87 menunjukkan variasi bobot karkas pada heifer sebesar $87,8 \%$ dipengaruhi oleh bobot potong dan $12,2 \%$ sisanya dipengaruhi oleh faktor lain di luar kedua faktor tersebut.

Korelasi bobot karkas dengan bobot tulang dan bobot lemak antara heifer dan steer ditampilkan pada Gambar 3 dan 4. 


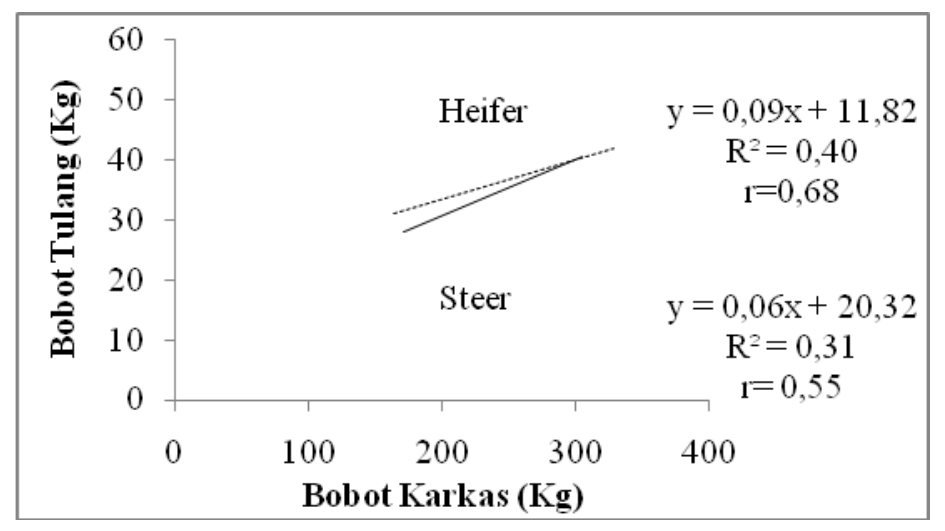

Gambar 3. Hubungan antara bobot karkas dengan bobot tulang heifer dan steer

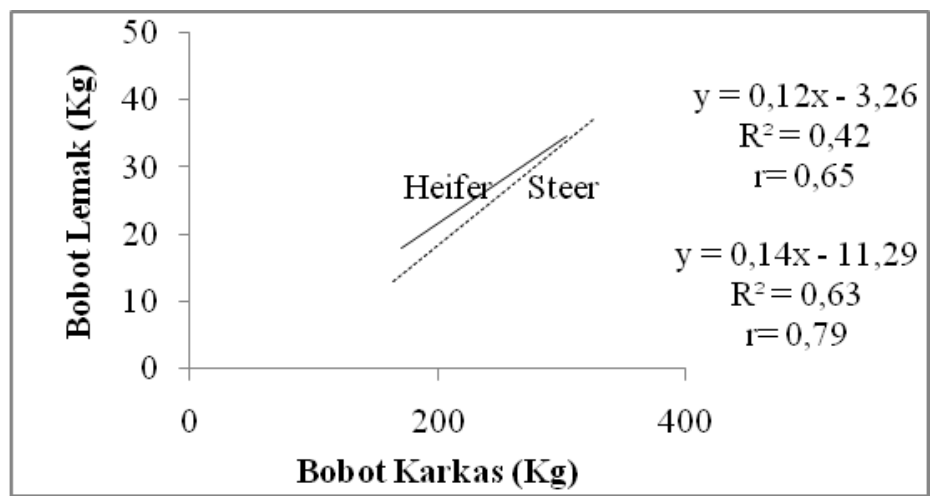

Gambar 4. Hubungan antara bobot karkas dengan bobot lemak heifer dan steer

Gambar 3 dan 4 menunjukkan korelasi antara bobot karkas dengan bobot tulang dan bobot lemak sapi BX heifer dan steer. Heifer mempunyai hubungan yang lebih erat dibandingkan dengan steer pada bobot karkas dengan bobot tulang, namun heifer mempunyai keeratan hubungan yang lebih rendah dibandingkan dengan steer pada hubungan antara bobot karkas dengan bobot lemak.

\section{KESIMPULAN DAN SARAN}

\section{Kesimpulan}

1. Bobot karkas heifer pada kelompok umur $\mathrm{PI}_{0}$ dan $\mathrm{PI}_{1}$ lebih besar daripada steer secara berurutan yaitu 228,46 $\mathrm{kg}$ : $192,50 \mathrm{~kg}$ dengan persentase karkas sebesar $(54,51 \%$ : $54,37 \%)$ dan $247,20 \mathrm{~kg}: 242,93 \mathrm{~kg}$ dengan persentase karkas $(54,91 \%$ :
54,89\%). Bobot karkas heifer pada kelompok umur $\mathrm{PI}_{2}$ lebih kecil dari pada steer $258 \mathrm{~kg}$ : $280 \mathrm{~kg}$ dengan persentase karkas $(54,29 \%$ : $55,40 \%$ ). Steer mempunyai rata-rata persentase karkas yang lebih tinggi dibandingkan heifer $(55,01 \pm 2,50 \%$ : $54,65 \pm 2,22 \%$ ). Produktivitas karkas tertinggi terdapat pada steer kelompok umur pemotongan $\mathrm{PI}_{2}$ $(55,40 \pm 2,44 \%), \quad$ sedangkan produktivitas karkas terendah terdapat pada heifer kelompok umur $\mathrm{PI}_{2}(54,29 \pm 1,83 \%)$.

2. Bobot daging, tulang dan lemak hiefer pada kelompok umur $\mathrm{PI}_{0}$ berturut-turut adalah $(166,19 \mathrm{~kg}$, $33,80 \mathrm{~kg}$ dan $25,29 \mathrm{~kg}$ ) lebih besar daripada steer yaitu $(139,87 \mathrm{~kg}$, $32,40 \mathrm{~kg}$ dan 17,52 kg). Bobot daging, tulang dan lemak hiefer pada kelompok umur $\mathrm{PI}_{1}$ berturut-turut 
adalah $(182,11 \mathrm{~kg}, 34,58 \mathrm{~kg}$ dan $27,65 \mathrm{~kg}$ ) sedangkan steer adalah $(179,38 \mathrm{~kg}, 36,62 \mathrm{~kg}$ dan $23,85 \mathrm{~kg})$.

Bobot daging, tulang dan lemak hiefer pada kelompok umur $\mathrm{PI}_{2}$ berturut-turut adalah (190,49 $\mathrm{kg}$, $36,88 \mathrm{~kg}$ dan $28,17 \mathrm{~kg}$ ) sedangkan steer adalah $(206,50 \mathrm{~kg}, 38,06 \mathrm{~kg}$ dan $31,58 \mathrm{~kg}$ ).

3. Steer mempunyai korelasi yang lebih tinggi dibandingkan dengan heifer pada hubungan antara bobot potong dengan bobot karkas $\left(\mathrm{R}^{2}=0,90\right)$ dan juga bobot karkas dengan bobot daging $\left(\mathrm{R}^{2}=0,97\right)$ dan bobot karkas dengan bobot lemak $\left(\mathrm{R}^{2}=0,63\right)$, sedangkan heifer mempunyai keeratan hubungan yang lebih tinggi pada hubungan antara bobot karkas dengan bobot tulang $\left(R^{2}=0,40\right)$.

\section{Saran}

Disarankan untuk mendapatkan produktivitas karkas yang optimal, umur pemotongan yang ideal untuk sapi BX adalah steer ketika sapi berumur 2,5 hingga 3 tahun dan heifer ketika sapi berumur dibawah 2,5 tahun.

\section{DAFTAR PUSTAKA}

Berg, R.T., and Butterfield, R.M. 1976. New concepts of cattle growth. Sydney University Press, Sydney. Dalam Usmiati, S., dan Setiyanto, H. 2008. Penampilan karkas dan komponen karkas ternak ruminansia kecil. Hlm: 371-380. Prosiding Seminar Nasional Teknologi Peternakan dan Veteriner. Balai Besar Penelitian dan Pengembangan Pascapanen Pertanian Bogor.

Bertram, J. D., and Oliver, M. R. 1990. Lot feeding of beef cattle. Technical Bulletin No. 13. Northen Theritory. Dalam Usmiati, S., dan Setiyanto, H. 2008. Penampilan karkas dan komponen karkas ternak ruminansia kecil. Hlm: 371-380. Prosiding Seminar Nasional Teknologi Peternakan dan Veteriner. Balai Besar Penelitian dan Pengembangan Pascapanen Pertanian Bogor.

Hafid, H. H. 2002. Pengaruh pertumbuhan kompensasi terhadap efisiensi pertumbuhan sapi brahman cross kebiri pada penggemukan feedlot. Jurnal Ilmu-ilmu Pertanian Agroland. Fakultas Pertanian Universitas Tadulako Palu. 9 (2): 179 - 185

Hafid, H. H., dan Priyanto, R. 2006. Pengaruh konformasi butt shape terhadap karakteristik karkas sapi Brahman cross pada beberapa klasifikasi jenis kelamin. Media Peternakan. 29(3): 162-168.

Kuswati, Kusmartono., Susilawati, T., Rosyidi, D., dan Agus, A. 2014.

Carcas characteristics of Brahman crossbreed cattle in Indonesia feedlot. J. Agricultural and Veterinary Sciences(7): 19-24.

Mustofa, Z. 2001. Analisis pemasaran sapi potong di kabupaten blora Jawa tengah. Prosiding Seminar. Fakultas Peternakan Institut Pertanian Bogor. Bogor.

Priyanto, R., and Johnson, E. R. 2011. Muscle growth and distribution in fattening sterr of different breeds.Media Peternakan: 19-22.

Purbowati, E. A., Purnomoadi, Lestari., dan Kamiyatun. 2011. Karakteristik karkas sapi Jawa (Studi kasus di RPH Brebes, Jawa Tengah). Prosiding Seminar Nasional Teknologi Peternakan dan Veteriner.

Sastrosupadi, A. 2000. Rancangan percobaan praktis bidang pertanian. Kanisius. Yogyakarta. 
Soeparno. 2005. Ilmu dan teknologi daging. Gadjah Mada University Press. Yogyakarta.

Sugiyono. 2006. Statistik untuk penelitian. Cetakan Ketujuh. Alfabeta. Bandung.

Usmiati, S., dan Setiyanto, H. 2008. Penampilan karkas dan komponen karkas ternak ruminansia kecil. Hlm: 371-380. Prosiding Seminar Nasional Teknologi Peternakan dan Veteriner. Balai Besar Penelitian dan Pengembangan Pascapanen Pertanian Bogor. 